\title{
INTOXIĊATION AS A DEFENSE TO AN EXPRESS CONTRACT
}

It seems that the earliest discussion in the books in which the question is discussed, whether the mental imbecility of a party at the time of his performance of an act invalidates that act, is to be found in Britton, ch. $28 \mathrm{f} .66$. where the plea of insanity was held to be a good defense to an action on a bond. Subsecutenty grave doubt arose as to the propriety of permitting a man to disable and stultify himself, and it was held by Littleton that the law did not permit a man to plead drunkenness as a defense to either a civil or criminal liability. This principle of law as cuunciated by Littleton and fully approved by his great scholastic conmentator, Lord Coke, has the support of some few scattered early English anthorities, anong which are 5 Edw. III, jo: 39 Hen. VI, 42, and 35 Ap. PI. 10. The doctrine as laid down by Littleton and Coke, is based upon the absurd, irrational and extraordinary reasoning. that if the party was non compos mintis at the time of the performance of the act he afterwards desired to invalidate, he conld not have known that he executed the act. ${ }^{1}$ Cotwithstanding the absurdity of the doctrine and the reasoning and strong objections urged in opposition thereto by Fitzherbert, it became so deeply rooted that for a time it prevailed as a maxim of the ancient common law:" In Strond v. Marshals ${ }^{3}$ it was again held that insanity could not be pleaded as a defense to an action on a bond and in this case the opinion of Fitzherbert. given in N. B. 202. was expressly: repudiated, while in Bcicrly's Cuse" it was even clenied that in Fitzherbert's time insanity had been allowed as a defense to an action on a contract. and the maxim of the common law was said to be that "a man shall not disable himseli." The adoption of this maxim. if "maxim" it can be called, in the Bererly case was not approved in subsequent cases.

\& Co. Litt. 172.

Jenk. Cent. \$a

- Cr. Eliz. 398.

- Printed in Thomas's \& Francis's ed. 2 Reports, 658.

(34) 
Thompson r. Liach" decided that an act of an insane person was roid for the perplexing reason that it is not for want of right that an insane ;erson cannut aroid his own feoffment, but by reason of his personal incapacity.

In lates 5 . Bon" after reviewing the opinion of Baron Pengelley in Smith $r$. Carr, decided in 1728, it was held that insanity may be shown in evidence under the plea of non est factum. : Cotwithstanding. Lord Coke in approving the doctrine as enumciatcl by Littleton," places the drunkard in his fourth classification of insane persons, sajing his drunkenness shall give no benefit to him or his heirs. The more modern English authurities entertain a more charitable view of the drunkard, and classifying him as one qui gandit lucidis inferiollis. hold that complifi intuxication is a gooxl sleiense to an action on a bond and may be given in cridence on the plea of non cst fuctum. Lord Ellenborungh said, in Pitt s. Similh:"

-Intoxication is good evidence under the plea of non est factum, to a deed; non concessit to a grant, and "ton assumpsit to a promise." -

The maxim of Littleton and Coke has been utterly exploded, and the English law on the subject is now settled in accordance with the rule laid down by Britton, whicls appears to have been approved and alopted in most civilized countries; ${ }^{10}$ and this rule is certainly in accord witl reason, humanity and natural justice. even though it was necessary for the courts to distinguish all ay the maxim of Coke and Littleton.

Lord Coke says the right of a defendant to plead intoxication in aroidance of his contract was never recognized at common law, and that although he who is drunk for the time being is non compos mintis, yet his drunkenness shall not cx-

1 Lord Raymond, 312.

- Stra 1104

- Buller's X. P. 172; Fenton 5. Holloway. I Stark. X. P. C. 126; Pitt. v. Smith, 3 Camp. 33.

'Coke on Littleton, 24i, 2. n. 2 ".

3 Camp. 33.

"I Evans, Pothier, 29. 
tenuate his act, nor be tumed to his avail."1 Pothier, however, in stating the rules, said:

"It is evident that drunkenness, when it goes so far as evidently destroying the reacon, renders a person in that state, so long as it continues, incapable of contracting." 12

The trend of modern authority follows the rule of Pothier and sustains the right of a person to plead his own drunkenness in avoidance of his contract, where the intoxication is of such a legree as to incapacitate him from comprehending the nature of his transaction. ${ }^{13}$

Lord Coke, although admitting that a person in a complete state of intoxication is for the time insane, denies that drunkenness can be set up in aroidance of a contract under any' circumstances; and he makes no distinction between civil and criminal cases, refusing to qualify his doctrine eren where the intoxication was procured by the comnivance of another who could be or has been benefited thereby. He lays down the broad principle that drunkenness cannot be pleaded as an excuse for the commission of a crime or in aroidance of a civil obligation. Sir IV'illiam Blackstone considers the rule of Coke and Littleton to be based upon false reasoning: ${ }^{14}$ In Yates $x$. Bocn, ${ }^{13}$ the defendant souglit to give evidence of intoxication. The Chief Justice hesitated before admitting the evidence upon the authority enunciated in Bererley's case, that a man shall not in law be allowed to stultify himself, but under the ductrine of Thompson v. Lcach, ${ }^{16}$ where it was held that the deed of a man non compos mintis was void for want of capacity to bind himself or his rroperty, admitted the evidence. And Lord Mansfield so ruled

"Coke Lit. 124a.

- Pothier's Obligation on Contracts, vol. 1, p. 49

Eskine Inst. 814, ef seq.; Fonblanque Eq. 6; : Harman r. Johnston, I IIc.Arthur, 139: Clifton v. Davis. I Pars. S. Eq. Cas. 31 ; IVade v. Colbert, 12 Am. Dec. 652: Buroughs v. Richman, 13 \$. J. L 233. 23 Am. Dec. $717:$ Bursinger v. Bank, 6; Wis. 75.38 Am. Rep. 8+8; Reynolds v. Walker, I Hash. (Va.) 164: Bush r. Brenig. 113 Pa. 310. 57 Am. Rep. 469 ; Buxton vi: Buxton, 2 Aik. (it.) $16 \% 16 \mathrm{Am}$. Dec. 691: Fouler v. Mleadow Brook Water Co. $203 \mathrm{~Pa}$. 473. 5 ; Atl. 959; Ewell's Ld. Cas. 728.

* 2 Black. Com. 29r.

2 Stra. Iras.

3 Mad. 391 . 
in the case of Chambcrlain of London r. Erans, mentioned in the appendix to Blackstone's Commentaries." The case of Thompson r. Liach has not only the approval of Mr. Justice Blackstone and Lord Mansficld. but also the sanction of Chitty, Selwyn, Phillips and the most approved clementary English writers and commentators. With one or two exceptions Biz'rley's Case has never been recognized as law by any of the courts of the Lnited States; and in this country it has been almost uniformly held that a party who enters into a contract when in a complete state of intoxication may plead his drumkenness to avoid the performance of the obligation. ${ }^{18}$

The great weight of modern authority buth American and English adhers to the principle without qualification. that intoxication is a defense to a civil contractual obligation regardless of the fact that the intoxication was procured by the party claiming the benefit of the agreement. In Gore v. Gibson ${ }^{19}$ it was held that in an action by an endorsee against an endorser of a bill of exchange the defense, that there was such a degree of intoxication at the time of the endorsement as to deprive the endorser of his understanding. reason and ability to comprehend the nature of his endorsement, was a good answer to the action and that this was not merely an argumentative traverse of the endorsement. The line of reasoning has the approval of Clancellor Kent and many other eminent American authorities. ${ }^{20}$

Intoxication does not render a contract roid but roidable.21 It is true that in Gorc v. Gibson 22 the judges used the word "roid," but from the reasoning in that case it may well be inferred that a contract made with a drunkard is merely voidable, and that

${ }^{17}$ Letters of Mr. Justice Blackstone, Philadelphia, 1;/3. p. 149; \& Desaus. Ch. Rep. 364.

20 Rice v. Peel, 15 Johns. (N. Y.) 503; Arnold r. Hickman, 6 Alunf. (Va.) 15 .

${ }^{20} 13$ Mees, \& W. 623.

- 2 Kent Com. (13th ed.) 45I; Reynolds v. Walker, I Wash. (V2) 164; Curties v. Hall, I Southard (N. J.), 361 ; State Bank v. IIcCoy, $69 \mathrm{~Pa}$. 204; Duncan r. AlcCullan, 4 S. \& $\mathrm{R}$. ( $\left.\mathrm{Pa}_{2}\right)$ \&4: Clark v. Cardwell, 6 lliatts (Pa), 139; Wigglesworth v. Steers, 1 H. \& MI. (Va.) zo; Frceman v. Staats, 8 ... J. Eq. 814

${ }^{21}$ Story on Contracts, 88; ; Bates v. Ball, $; 2$ Inl. Io8; Matthews v. Baxter, L. R. 8 Ex. 132.

${ }^{2} 13$ Mees \& W. 623 . 
the judges meant merely that a drunken man's contract, if not ratified by him when soler, could not be enforced against him. In Mattheri's v. Baxter ${ }^{23}$ Pigott and Pollock, Barons, commenting on Gore r. Gibson, expressed the opinion that the contract of a drunken man was roidable and not void: and this represents the trend of modern authority: It It may be fairly decluced from some of the English cases that a distinction is drawn between the effect of a complete state of intoxication which deprives a man of his reason, and a state of drunkenness which merely prevents him from forming a rational judgment, holding that in the former the contract is roid $a b$ initio and in the latter voidable merely. ${ }^{25}$ In II'ilson '. Bigger ${ }^{24}$ it was held that a party reduced to such extreme debility by intoxication as to be unable to sit up unsupported, or to hold his pen and make his mark unless the pen is held for him, can no more execute a contract of convejance than if he were completely drunk.

The ancient common law rule repudiated by Coke and Littleton appears to have the support of at least one American authority. Drummond v. Hopper ${ }^{28}$ held that a contract made with a man in a state of complete intoxication was absolutely roid, and this opinion is based upon the anomalous dictum of Lord Coke, who declared that,

"Although, he who is drunk, is for the time, non compos mentis, yet his drunkenness does not extenuate his act or offence, nor turn to his avail; but it is a great offence in itself, and therefore aggrasates his offence, and doth not derogate from the act which he did during that time, and that as well in cases touching his life, his lands, his goods, or any other thing that concerns him."

In another case. Har'kins v: Cammon, ${ }^{28}$ the court stated that a contract made by a drunken man was void: but the actual de-

L. R. 8 Ex. 132, 12 L. J. Ex. 73

* Bush v. Brenig. $113 \mathrm{~Pa}$ 310. 6 Atl. 86; Carpenter v. Rorgers, 6r Mich. 384. I Am. St. Rep. 395; Matthews s: Baxter, L R. 8 Ex. 132, 42 L. J. Ex. 73 ; Chitty on Cont. (Irth Am. ed.) 192: Wald's Pollock on Cont. 92 cited.

${ }^{3}$ Cooke v. Clayworth, 18 les. 12; IVald's Pollock on Cont. 91, and cases

*IV. \& S. (Pa) 111.

" + Harr. (DeL) $35 \%$

+ + Rich. L (S. Car.) 136. 
cision was that a contract made under such conditions was capable of ratification by the party when he came to his sober senses.

The rule of the civil law is stated by Pothier as follows:

-It is erident that drunkenness, when it goes so far as to absolutely dethrone the reason. renders a person in this state, so long as it continues, incapable of contracting, since it renders him incapable of consent."

This is mone consistemt with reason and justice than the maxim laid down by Lord Coke who terms a drunkard diamon zoluntarins. and one who by his own act for a time deprives himself of memory and understanding.: Sir IVilliam Blackstone and Fitzherbert did not scruple to reject the maxim of Littleton and Coke although it met with the approval of the juciges during the reign of Henry VI, wherein it was decided that a party was not permitted to disable himself by pleading incapacity and an heir was barred of his right of entry by the feoffment of his insane ancestor. This theory of Lord Coke is based on two conflicting reasons, and places its author in the paradox and anomaly of occupying two synchronous and antagonistic positions, and is unlike every other part of our great system of jurisprudence which is reducible to consistent and immutable principles of reason and natural justice. Later opinions recognizing the fallacy and the inconvenience of the rule in Bcrerley's Case have totally disregarded that isolated and anomalous maxim; and although the intoxication may have been effected by the roluntary act of the party pleading it as a defense to the contractual obligation, modern courts exercise jurisdiction for the protection of the drunkard..$^{30}$ A rery able English authority declared:

"It never can be said that 2 person absolutely drunk has that freedom of mind generally esteemed necessary to a deliberate consent to a contract. The reasoning faculty is for a time deposed. At law it has been held upon a plea of non cst factum, the defendant may give eridence that they made him sign the bond when he was so drunk that he did not know what he did. So a will made by a drunken man is invalid.

- Bererley's Case. \& Coke. 124

* Waldron v. Angleman, ;1 T. J. L. 166, 38 Atl. Rep. 568 
And will a court of edguity be less indulgent to human frailty? It seems to be a fraud to make a contract with a man who is so drunk as to be incapalie of deliberation." 22

According to the weight of authority, the maker of a note, as between himself and the payee, may plead intoxication in avoidance of payment if he can show such a degree of intoxication at the time of the execution, which would have drowned reason, memory and julgment and the impairment of his mental faculties to the extent of rendering him non compos mentis, although there is no evidence that any person connected with the transaction aided or procured his intoxication. This defense may also be set up against those taking the note with full knowledge of the circumstances; but on the ground of public policy and the necessities of trarle the defense of intoxication is not available against an innocent holder for value. ${ }^{32}$

The rule is well stated by Mr. Justice Williams in State Bank v. McCoy: ${ }^{33}$

"The note of an insane person or of one perfectly imbecile, which he has been influenced to sign by fraud or imposition, is void in the hands of an innocent holder for value, without notice of the maker's condition when it was given. There is a difference between the cases. Insanity or total imbecility is a permanent state or condition of the mind, disabling one from taking care of himself. Drunkenness is a temporary disability voluntarily produced. . . . If a man voluntarily deprived limself of the use of his reason by strong drink, why should he not be responsible to an innocent party for the acts he performed while in that condition? It seems to be he ought on the principle that where a loss must be borne by one of twu innocent persons, it shall be borne by him who occasioned it. But there is another and controlling reason for holding the maker liable to the endorsee in such cases, founded on principles of public policy and the necessities of commerce."

If a party having the intent of aroiding the contract voluntarily procures his intoxication for the purpose of entering into

2 I Maddocix's Ch. Pr. 2.33; Story's Eq. Jur., \$23r.

"State Bank v. IIcCoy, $69 \mathrm{~Pa}$ 204; Gore v. Gibson, 13 II. \& IV. 623; Molton v. Camroy, 2 Exch. $48 ;$; IIigglesworth r. Steers, I H. \& N. (Va.) 70; I Danl. leg. Inst. \$21 ; Birdson v. Birdson, 2 Head (Tenn.), 287.

$=69 \mathrm{~Pa} .206$. 
i1, the fraululent intent preceles his intoxication and renders him incompretent to plead his condition as a defense. ${ }^{34}$

Although the anthorities seldum discuss the degree of intoxication which is necessary to aroid a contract, nevertheless there is some variance in the decisions. Pothier ${ }^{35}$ holds that a degree of drunkenness sufticient to take away reason renders the person in that condition incapable to contract, since he is nuable to assent. Harmon v. Johnson, ${ }^{\circ 0}$ held: there was no error in the following instruction:

"It is not necessary, in order to render the deed of the deiendant invalid, that at the time of the exccution and acknowlchlgement he was entirely demented by drink, but his act will ire rendered void if he was in such a condition of mind that he could not comprehend what were the terms and conditions of the instrument."

Cpon appeal this case was decided by the Supreme Court of the Lnited States, ${ }^{32}$ where Mr. Justice Bradley, approving the principle laid down by Pothier said:

"Both minds must meet in such transaction, and if one is so weak, unsound and diseased that the party is incapable of understanding the nature and quality of the act to be performed, or its consequences, he is incapable to assent to the terms and conditions of the instrument, whether that state of his mind was produced by mental or plysical disease, and whether it resulted from ordinary sickness, or from accident, or from debauchery, or from habitual and protracted intemperance." 39

In some of the cases above cited the governing principle is pronounced. that he who seeks relief on the ground of intoxication must in some manner show that he has repudiated his agreement made while in a state of intoxication; and if the position of the parties has been so altered since the making of the

"I Danl. Neg. Inst., \$215.

*Vol. 1, c. 1, a4, हु.

* MacArth (D. C.) 339

"94 U. S. 3;r.

* Clifton r. Daris. I Pars. Eq. 31 : Johnson v. Medlicott, 3 P. Wm. 131; Cory s. Cory. I Ves. 19: Shaw s. Thackray, I Sm. \& Giff. 537; Warbison v. Lemon, 3 Blackf. 51 ; Crane v. Conklin, Saxt. 346; Maxirell v. Pittenger, 2 Green Ch. 156 . 
contract that the other party wonld be prejudiced by a rescission. then he who seeks rescission must attempt to restore the siatus in quo, unless the intoxication was procured by the contrivance of the otlier party. And this principle of law seems sound and consistent with reason.

In law the contract of an intoxicated person is voidable for lack of capacity to assent, and equity assumes jurisdiction in such cases on the gronnd of fraud or imposition. Equity will avoid a contract where the intoxication has been procured by the connirance of the other party to the contract, or where the drunken party has been taken adrantage of or imposed upon by the other party. If neither fraud nor imposition can be shown and the intoxication was soluntarj: equity will not afford relief merely on the ground of intoxication, but leares the party to his defense at law. ${ }^{10}$

The New Jersey rule appears to be, that in order to avoid 2 contract in equity for reason of intoxication it must be clearly demonstrated either that the drunkenness was procured by the connivance of the other party who received the benefit of the contract, or that an undue advantage was taken of the situation."

The rule promulgated by Sir Joseph Jekyl and approved by that very learned American author, Mr. Pomeroy, that equity has jurisdiction to relieve and especially, if the intoxication was occasioned by the contrivance or fraud of the other party and is made so excessive as to deprive the party asking for relief of his reason and understanding, is based upon the principle that a person cannot seriously and deliberately consent while in such

- Carpenter v. Rodgers, 6I Mich. 384, 28 X. IV. 156

- Bowen v. Clark, 37 Fed. Cas. No. 1, j21; Butler r. Ifulrihin, 4 Eng. Reprint. 49: Say v. Barwick, I Ves. \& B. 195; Cooke v. Clayworth, I8 Ves. 12: Osmond r. Fitzros, $3 \mathrm{P}$. IVm. 139: Reynolds $v$. Walker, I Wash. (Va) 164; Iillshire v: Marshall, 14 L T. R. X. S. 396; Rodman v. Zilley. 1 I. J. Eq. 320: Reinicker r. Smith, 2 H. \& J. (IId) 421 ; Storg's Eq. Jr, \$231: 2 Kent Com. 453; O'Conner v. Rampt. 29 i. J. Eq. 156; if Cive vo6; 2 Pom. Eq. Jur., \$494

"Crane v. Conklin. I x. J. Eq. 346; Rodman r. Zilles, Id 320; Pittenger vs. Pittenger. 3 X. J. Eq. 35;: Warrack $v$. Campbell, 25 X. J. Eq. \&85. Tone of these cases show that 2 complete case of intoxication was prored. 
a state. and without this ability to reason and consent no contraci entered into ly a jerson should lee enforceable against him. ${ }^{2}$ The old anthorities which were based upon the dictum of Lord Coke and supported by some loose decisions in the Year Books churing the reigns of Edward III and Fenry VI and a few other scattering authorities. have now been entirely abolished: and the rule now is, that an intoxication which is absolute and used by the other party to the contract to his advantage. is sufficient foundation for equitable relief. ${ }^{43}$. And. a forfiori, even though the intoxication is only partial, if produced by the connivance of the other party who made use of the opportunity by imposition or uniairness, equity will grant appropriate affirmative relief." The case of Pittengir v. Pittinger ${ }^{\text {}}$ contains a dictum which may be fairly construed as in conflict with the above stated pinciple. However. it must be renembered that courts of equit; are very cautious in affording relief on the ground of intoxication and the remedy is seldom given unless coupled with the drunkenness there is also shown a conduct plainly inequitable practiced by the other party. ${ }^{40}$

Mr. Justice Story said:

-Courts of equity, as a natter of public policy, do not incline, on the one hand, to lend their assistance to a person who has obtained an agreement or a deed from another in a state of intoxication; and, on the other hand. they are equally unwilling to assist the intoxicated party to git rid of his agreement or deed merely on the ground of intoxication at the time of the execution. They leave the parties to their ordinary remedies at law, unless there is some fraudulent contrivance or some imposition. It is upon this special ground that courts of equity lave acted in cases where a broader principle has sometimes supposed to have been held." " "I

"Spier r. Higgins. decided at the rolls. 1814 I Mad. Ch. 305: 2 Pom. Eq. Jur. 949

Cook r. Clayton, 18 Ves. 12: Schackleton v: Sebree, 86 In. 616; Prentice r. Achom. 2 Paige (I. Y.), 30; 2 Pom. Eq. Jur.. \$ 949

"O'Connor r. Rempt, $\Rightarrow 9$ \$. J. Eq. 156.

${ }_{3}$ X. J. Eq 186 .

* Schram r. O'Connor. 98 Ill 5j9; Harbison v. Lemon, 23 Am. Dec 376; Selah :. Selah. 23 X. J. Eq. 185.

"Story"s Eq. Jur. \$\$231-232 
Gathered from the authorities above mentioned the modern rule goterning the question of intoxication as a defense to an express contract, may be stimmarized as follows:

If at the time of making the coitract, the party seeking to aruid it was in such a state of intoxication that he was incapable of assenting to the agreement and has not ratified the transaction in his solver senses, the obligation is roidable, especially if any advantage has been taken of the intoxicated person and fraud or imposition has been practiced by the other party to the contract. A contract which may be invalidated by reason of intoxication can be ratified by the intoxicated party when sober and will thereafter be binding. Intoxication of the maker of a negotiable note may invalidate it as against a bona file holder with knowledge of the circumstances, but is not available as a defense against a bona fidc endorsee for value, without notice of the circumstances of the transaction. A drunkard may be held liable upon implied contracts for his actual necessities. If the intoxication was procured by the contrivance of the other party, or if either fraud or imposition has been practiced by or through the party benefited. the intoxicated party nay institute a suit in equity for the cancellation or rescission of the obligation; but before a court of equity will grant the relief the party seeking this aid must return the consideration he has received. Intoxication may be pleaded by the intoxicated party, his personal representative or heirs, but cannot be plearled by a third person.

Hampton, Va.

Sidney J. Dudley. 